\title{
Relationship Between Students' Self Confidence Attitude and Assertive Attitude Among Student of Grade XI at SMAN 2 Gorontalo
}

\author{
Irvan Usman ${ }^{\mathrm{a}}$, Moh. Rizki Djibran ${ }^{\mathrm{b}}$, Sukria Ahsan ${ }^{\mathrm{c}}$ \\ aDepartment of Guidance and Counseling, State University of Gorontalo \\ bDepartment of Guidance and Counseling, State University of Gorontalo \\ cDepartment of Guidance and Counseling, State University of Gorontalo \\ e-mail: ivanbkfip0277@gmail.com
}

\begin{abstract}
School is considered a place where the students are familiar with new attitudes in life. It is expected that they can recognize a new positive attitude, such as an assertive attitude. The aim of the research is investigating students' self-confidence behavior with assertive at grade XI of SMAN 2 Gorontalo. The population of this research was 310 students, while its samples were 31 people determined by random sampling. Data are collected through a scale of self-confidence and an assertive attitude. The data were analyzed with regression analysis. Research findings showed that there is a significant correlation between students' self-confidence and assertive attitude. Variation of students' self-confidence is $44,19 \%$ for assertive attitude, while the remaining $55,81 \%$ is followed by other behaviors and attitudes that are not revealed in this research. This study concludes that there is a correlation between self-confidence and assertive behavior on grade XI students of SMA N 2 Gorontalo.
\end{abstract}

\section{Keywords: Assertive Attitude, Self-Confidence Behavior, Students}

\begin{abstract}
Sekolah merupakan wadah bagi siswa untuk mengenal perilaku-perilaku baru dalam kehidupannya. Diharapkan siswa mampu mengenal perilaku baru yang positif seperti perilaku asertif. Tujuan penelitian ini adalah untuk mengetahui hubungan antara sikap percaya diri dengan perilaku asertif siswa kelas XI SMA Negeri 2 Gorontalo. Populasi penelitian adalah 310 orang, sampel yang diambil sebanyak 31 orang dengan menggunakan teknik random sampling. Pengumpulan data dilakukan dengan menggunakan skala sikap percaya diri dan skala perilaku asertif. Teknik analisis data menggunakan analisis regresi. Hasil dari penelitian menunjukkan bahwa terdapat hubungan yang sangat signifikan antara sikap percaya diri dengan perilaku asertif pada siswa. Variasi yang terjadi pada sikap percaya diri siswa adalah perilaku asertif sebanyak 44,19\%, sedangkan sisanya $55,81 \%$ diikuti oleh sikap dan perilaku lain yang tidak diungkap pada penelitian ini. Berdasarkan hasil penelitian yang telah dilakukan, dapat disimpulkan bahwa terdapat hubungan antara sikap percaya diri dan perilaku asertif siswa kelas XI SMA Negeri 2 Gorontalo.
\end{abstract}

Kata Kunci: Perilaku Asertif, Sikap Percaya Diri, Siswa

\section{INTRODUCTION}

A school is a place for individuals to gain knowledge and a place for them to interact with friends, teachers, and others. A school is also a place for each individual to know new behaviors. It is expected that students will be able to know new positive knowledge, such as assertive behavior. Assertive behavior can help students' increase their learning achievement (Setyowati \& Dwikurnaningsih, 2014) through assertive behavior, students can state their opinion in discussion within the class (Arumsari, 2017).

Abidin (2011:130) stated that the characteristics of assertive person-oriented around having good self-confidence, the ability to propose ideas and expressions fear and communicate fluently with others.

Observation on grade XI of SMAN 2 Gorontalo showed that students' assertive ability was still meager. This was evident in their inability to propose their ideas, fear of communicating with others, and fear of annoying others when they talk.

DOI : https://dx.doi.org/10.26486/ijagc.v1i2.1145

URL : http://ejurnal.mercubuana-yogya.ac.id/index.php/IJAGC/index

Email: ijagc@mercubuana-yogya.ac.id 
Confidence is one of the factors that can make someone have an affective attitude (Suhartini \& Reswari, 2011). Students who have confidence can actualize their full potentials. Ernawati (2012) mentioned that confidence is a faith within oneself about his/her ability, not relied upon others, able to think positively, hence able to think positively, that person can be responsible for what she or he has done, and also able to see the reality objectively.

Based on the description above, this study was aimed at finding out the correlation between confidence and assertive attitude of grade XI students in SMA N 2 Gorontalo.

Abidin (2011) wrote that assertive behavior is a behavior where individuals can express their thoughts, feelings, and willingness to correctly, honestly, openly, responsibly, directly, confidently, and persistently on what he/she believes without any fears toward others, and without neglecting or hurting others, and without violating others' rights.

Stein \& Howard in Miasari (2012) argued that assertive attitude also means as the ability to disagree with others without manipulation and emotional reason, and able to last in the correct path, by defending their opinion by observing others' opinion.

Based on the scholars' views above, it can be concluded that assertive behavior is one's behavior, in which he/she can express their thoughts without disparaging or hurting others.

\section{Aspects of Assertive Behavior}

1. According to Alberti \& Emmons (2001), there are several assertiveness aspects, such as:

2. Act according to his/her own will, which consists of the ability to make decisions, take initiatives, believe in what himself/herself said, able to determine objectives and work toward achieving those objectives, and able to participate in relationships.

3. Able to express feelings honestly and comfortably consists of the ability to voice disagreement, anger, show affection, and friendship toward others, show support, and act spontaneously.

4. Able to defend him/herself. Consists of ability to say no when needed, able to openly respond to critics, disparagement, and anger from others, and able to express and defend opinions.

5. Able to state opinion consists of the ability to state opinions and ideas, make changes, and respond to violations against himself/herself and others.

6. Disregard the rights of others. Consists of the ability to state critics fairly without threats, manipulation, intimidation, controlling, and hurting others.

\section{The basic concept of self-confidence}

Self-confidence is a positive thought and attitude which shows courage. According to Fatimah (2006), self-confidence is an individual positive attitude that one shows with courage. Fatimah further adds that self-confidence is a positive attitude that enables individuals to develop positive values for themselves, their environment, or the situation. Oxford Advanced Learner's Dictionary defines confidence as a trust in your ability to do something and to succeed (Rahayu, 2013).

Based on several arguments above, it can be concluded that self-confidence is a positive attitude to actualize one's potentials to achieve his/her goals in life.

Kumara in Yulianto \& Nashori (2006) stated that there are four aspects of self-confidence:

1. Confidence on his/her ability is a real trust toward the ability owned by an individual (Purnomo \& Harmiyanto, 2016) and has a positive attitude based on the confidence in his ability (Lauster, 2003).

2. Responsible for decisions and actions are individual willingness to bear all responsibility as the consequences of his/her decisions and actions. 
3. Responsibility to interact is an individual able to interact appropriately with the environment

4. The ability to accept critics is an individual ability to accept critics from others to correct mistakes (Risnawati \& Lipursari, 2016).

\section{Hypothesis}

This research hypothesis is "whether there was a correlation between self-confidence attitude and grade XII students" assertive behavior in SMA N 2 Gorontalo".

\section{METHODS}

The subject in this study is grade XI students of SMA N 2 Gorontalo. The samples in this study are taken using Random Sampling. Riduwan (2012) wrote that Random Sampling is a method of taking samples from members of the population randomly with no regard to the level in that population. The number of the population is 310 students, and the samples in this study are $10 \%$ or 31 students.

This study used two scales, self-confident attitude scale, and assertive behavior scale. Self-confident attitude scale consists of four aspects: a) confidence in his/her ability; b) responsible toward his/her decisions and actions; c) ability in interaction; and d) ability to accept critics.

Based on the validity test, out of 80 items, six items are eliminated. Thus, there are only 76 items. Reliability test toward the questionnaire against $r$ table $n=100$ and the significance level of $\alpha=0.05$, the $\mathrm{r}$ count value is 0.926 . Hence, the instrument reliability, $r$ count $=0.926>\mathrm{r}$ table $=0.195$. This comparison shows a significant result, which means these questionnaire instruments are reliable.

\section{FINDINGS AND DISCUSSION}

The hypothesis test on variable $X$ and $Y$ reveals the equation is $\hat{Y}=47,4083+$ $0,6062 \mathrm{X}$, which has been tested on the significance level of $\alpha=0.05$ as correlation, which happened among the population. Based on the samples taken from the population, it reveals that the self-confidence attitude and assertive behavior of students experience an increase. This equation means that the higher the self-confidence attitude, it will be followed by assertive behavior. Based on the significance test of the correlation coefficient, it is found that the tcount $=4.7923$ and the ttable $=2.46$ or that tcount is more significant than the table, or that the value of tcount is outside the acceptance range of $\mathrm{H} 0$, it can be concluded that the coefficient correlation is significant.

Through a simple correlational test, it is found that the value of $\mathrm{rxy}=0.6648$ with determinant coefficient $\mathrm{rx} 2=0.4419$ or $44.19 \%$. This means that $44.19 \%$ of the variation on self-confidence attitude is followed by assertive behavior, which means that there is a very significant correlation between self-confidence attitude and students' assertive behavior. The rest $55.81 \%$ is influenced by other factors outside this study. Whereas, based on the correlational coefficient test shows that the tcount value is more significant than the table or that the value of tcount is outside the acceptance range of $\mathrm{H} 0$. Therefore, $\mathrm{H} 0$ is rejected, and $\mathrm{H} 1$ accepted, which means that there is a significant correlation between self-confidence attitude and assertive behavior of students in SMA N 2 Gorontalo.

This study reveals that there is a very significant correlation between self-confidence attitude and assertive behavior, the higher one's self-confidence, it will be followed by assertive behavior. Assertive behavior is one's behavior that able to express his/her thoughts and opinion without demeaning or hurting others. This is also explained by Stein \& Howard (in Miasari, 2012) that assertive behavior also means the ability to disagree with others without using manipulation and emotional reasons, and able to hold on to the correct path, by 
defending his/her own opinion while at the same time respecting others and without hurting others.

Similar to what proposed by Abidin (2011), in which he proposed the several characteristics of assertive behaviors such as someone who has opinions from his/herself, has good self-confidence, able to state ideas and expressions without fear and communicate with others properly. Further, self-confidence attitude, according to Hakim (2002), is one's ability toward all plus aspects within him/herself and that confidence enables him/her to achieve various purposes in life.

Students who have high self-confidence can give themselves positive drives for themselves and their environment. This self-confidence also influences other behaviors, as Rahayu (2013) pointed out that self-confidence can influence the mental and character development of students. Strong students' character and mental will become substantial capital for their future; hence they can respond to various challenges realistically. Confidence in personal ability will make students able to state their opinions, confidence to speak in front of the class, work in teams, and easy to socialize.

\section{CONCLUSION}

This study concludes that there is a correlation between self-confidence and assertive behavior on grade XI students of SMA N 2 Gorontalo.

\section{REFERENCES}

Abidin, Z. (2011). Pengaruh Pelatihan Resiliensi terhadap Perilaku Asertif pada Remaja. http://lppm.trunojoyo.ac.id/upload/penelitian/penerbitan_jur nal/04_Pamator\%20v4\%20n2\%200kt\%202011.pdf.

Alberti, R., \& Emmons, M. (2001). Your perfect right (panduan praktis hidup lebih ekspresif dan jujur pada diri sendiri). Terjemahan: Ursula G. Buditjahja. Jakarta: PT Elex Media Komputindo.

Arumsari, C. (2017). Strategi Konseling Latihan Asertif Untuk Mereduksi Perilaku Bullying. Journal of Innovative Counseling: Theory, Practice \& Research, 1(1), 31-39.

Ernawati, S. (2012). Hubungan Antara Kepercayaan Diri dengan Kecenderungan Perilaku Agresif pada Siswa SMU N 1 Rembang. http://download.portalgaruda.org/article.php?article $=140448 \&$ val $=5790$

Fatimah, E. (2006). Psikologi perkembangan (perkembangan peserta didik). Bandung: Pustaka Setia.

Hakim, T. (2002). Mengatasi rasa tidak percaya diri. Jakarta: Puspa Swara.

Lauster, P. (2003). Tes kepribadian (Alih Bahasa: D.H Gulo). Jakarta: PT Bumi Aksara.

Miasari, A. 2012. Hubungan Antara Komunikasi Positif dalam Keluarga dengan Asertivitas pada Siswa SMP Negeri 2 Depok Yogyakarta. Empathy Jurnal Fakultas Psikologi, 1(2).

Purnomo, D.P., \& Harmiyanto. (2016). Hubungan Ketrampilan Komunikasi Interpersonal dan Kepercayaan Diri Siswa Kelas X SMAN 1 Garum Kabupaten Blitar. Jurnal Kajian Bimbingan dan Konseling, 1(2), 55-59.

Rahayu, A.Y. (2013). Anak usia TK menumbuhkan kepercayaan diri melalui kegiatan bercerita. Jakarta: Indeks. 
Riduwan. (2012). Belajar mudah penelitian untuk guru, karyawan dan peneliti pemula. Bandung: Alfabeta.

Risnawati, V.N., \& Lipursari A. (2011). Profesionalisme Kenierja Dosen ASM Santa Maria. Jurnal STIE Semarang, 3(2), 21-32

Setyowati, P.A., \& Dwikurnianingsih, Y. (2014). Meningkatkan Perilaku Asertif Siswa Kelas X SMA Kartika III-I Banyubiru Melalui Layanan Bimbingan Kelompok. Jurnal Setya Widya, 30(1), 8-16.

Suhartini, S., \& Reswari, O.S. (2011). Pengaruh Perilaku Asertif Terhadap Stress Kerja pada Karyawan Indoturbine Jakarta. Jurnal Aplikasi Bisnis, 11(9). 1355-1370

Yulianto, F., \& Nashori, F. (2006). Kepercayaan diri dan Prestasi Atlet Tae Kwon Do Daerah Istimewa Yogyakarta. Jurnal Psikologi Universitas Diponegoro, 3(1), 5562. 